\section{AJHSE Vol: 1 (1): 73-80, 2020}

Article Ref. No.: AJHSE-0101-04

Accepted Date: Jan. 02, 2020

(C) 2020. CC License 4.0

www.ajhse.org

CrossMark

$\leftarrow$ click for updates
African Journal of Health, Safety and Environment

An official publication of the

Applied Environmental Bioscience and Public Health Research Group

University of Benin, Benin City, Nigeria

Open Access | Bi-annual | Peer-reviewed | International

ISSN (Online): 2695-1819 | ISSN (Print): 2695-2386

\title{
PERCEPTION OF INHABITANTS IN URBAN SLUMS OF BOUAKE (COTE D'IVOIRE) ABOUT THE HEALTH RISKS OF UNSANITARY ENVIRONMENTS
}

\author{
${ }^{* 1}$ N'gattia, K. A., ${ }^{1,2}$ Kouassi, D. P., ${ }^{1}$ Coulibaly, D., ${ }^{1}$ Chérif, D. and ${ }^{1,3}$ Tiembré, I.
}

${ }^{*}$ Epidemiologic Surveillance Service, National Institute of Public Hygiene, Abidjan, Cote d'Ivoire.

"Phone: +22507992658 "Email: nka1706@gmail.com

${ }^{1}$ Epidemiologic Surveillance Service, National Institute of Public Hygiene, Abidjan, Cote d'Ivoire.

Phone: +22507984752 Email: daocoul@yahoo.fr

${ }^{1}$ Epidemiologic Surveillance Service, National Institute of Public Hygiene, Abidjan, Cote d'Ivoire.

Phone: +22507673123 Email: bekansy_1@yahoo.fr

${ }^{2}$ Department of Public Health, University Alassane Ouattara (UAO), Bouake, Cote d'Ivoire.

Phone: +22577121278 Email: damuspaquin@gmail.com

${ }^{3}$ Department of Public Health and Medical Informatic, University Felix Houphouet-Boigny, Abidjan, Cote d'Ivoire.

Phone: +2250707974572 Email: itiembre@yahoo.fr

\begin{abstract}
Wroughout the world, one-third of the urban population continues to dwell in unplanned neighborhoods mostly located within unhygienic slums. The impact on their health could be far-reaching. The present study, which was cross-sectional, examined the perception of people in urban slums of Bouaké, Cote d'Ivoire visà-vis the attendant health risks. Majority of respondents selected for the study had lived within the study area for at least 2 years. Two persons per household were selected for the study; including the head of the household and any other occupant within the ages of 8 and 15 years. Overall, 423 people were interviewed. The median age was 21 years, with an average residency of 14 years. A total of $98.8 \%$ of the respondents agreed strongly that living in slums exposed inhabitants to grave health risks. However, only $2.9 \%$ agreed that an unsanitary environment contributed to pollution of ambient air. The perception of health risks related to exposure to unsanitary slums was statistically associated with the age $(\mathrm{p}=0.0152)$ and the number of years of residency $(\mathrm{p}=0.0156)$. Although, the survey suggested that living in urban slums exposed inhabitants to health risks especially disease epidemics, the fact that these residences had subsisted for very long periods within these slums changed their perception about acceptability.
\end{abstract}

Keywords: environment, health risks, perception, unsanitary, urban slums, Cote d'Ivoire.

LICENSE: This article by African Journal of Health, Safety and Environment (AJHSE)is licensed and published under the Creative Commons Attribution License 4.0 International License, which permits unrestricted use, distribution, and reproduction in any medium, provided this article is duly cited.

COPYRIGHT: The Author(s) completely retain the copyright of this published article.

OPEN ACCESS: The Author(s) approves that this article remains permanently online in the open access (OA) mode. 


\section{INTRODUCTION}

The environment is a set of physical, chemical, biological and socio-economic, moral and intellectual likely to have a direct or indirect, immediate or future development of ecosystems and human activities (Clerc et al., 2017; Urbandt, 1963). To avoid the negative effects of a polluted-environment on health, people should keep it clean. Indeed, health and wellbeing require a clean and harmonious environment in which physical, psychological, social and aesthetic take their rightful place (Hayward et al., 2015).

However, a third of the global urban population continues to reside in unsanitary slums (Clerc et al., 2017). Poor hygiene in these areas offers bio-ecological conditions for the development of germs and pathogens responsible for many diseases (Gaisie, 1980). In 2012, 12.6 million deaths worldwide (13\% to 34\% of all deaths) were because of modifiable environmental factors including unsanitary. Also, in the group of children under five years, 16 to $38 \%$ of deaths could be avoided if the health risks because of polluted-environment were eliminated (Prüss-Üstün et al., 2016).

A quarter of the global disease burden and more than a third of that of children were because of unsanitary environments that could be eliminated (Prüss-Üstün et al., 2006). In many African countries, studies on the etiologies of unsanitary revealed the deficit of environmental hygiene management services and the obliviousness of the population and the lack of eco citizen's behavior (Ngnikam et al., 2007; Sy et al., 2014). To the causes are added the non-involvement of the people to different programs about unsanitary and the neglecting or the lack of knowledge on the negative impacts induced (Ngnikam et al., 2007). The ignorance of the negative impact of unsanitary violates the actions of the promotion of environmental hygiene. However, the morbidity and mortality related to environmental degradation have a significant cost to the community and its leaders. This shows the need for the support of all to environmental preservation policies. (Prüss-Üstün et al., 2016). Thus, this study aims to determine the perception of health risks by the inhabitants of urban slums in Cote d'Ivoire for finding strategies to solve unsanitary environment issues.

\section{MATERIALS AND METHODS}

This study was conducted in Koko, Djamourou, Dar-Es-Salaam, and Sokoura the urban slums of the city of Bouaké, Cote d'Ivoire. These areas are classified as urban slums because of the huge unsanitary environments, overcrowding and faulty arrangement. They are among the largest and most densely populated of the country (Djéké, 2015). The study population residents in these urban slums for at least one year. In this study, two persons per household with at least two years of residency were selected to make up the sample. These two persons were the head of the household and any child of that same household within the eight to 15 -year age bracket. This cross-sectional study was conducted for a month from February 26 to March 26, 2017. The sample size selected for the study was 423 people. For equal allocation, 53 heads of households and 53 children were interviewed per urban slum. A total 423 people, including 211 children and 212 heads of household were interviewed. A purposive sampling was conducted by visiting households near unsanitary places such as garbage dumps, sewage, and clogged gutters. Each of the two people surveyed per household was interviewed by a questionnaire. Data collected analyzed using STATA MP 12.0 software 
for statistical analysis. Quantitative data were described by the mean, standard deviation, range, while qualitative by proportion. The multivariate analysis for the definition of the model of the perception of health risks was performed with the statistical test of chi-square, the odds ratio and logistic regression with a significance level of 5\%.

\section{RESULTS}

A total of 423 people were included in the study with a median age of 21 ranging between 9 and 79 years. These people lived in urban slums for an average of 14 years. Artisans were the group with the highest proportion (35.7\%) followed by the pupils and students who were $35.5 \%$. The population of civil servants and service employees were $8.5 \%$ of the sample. Regarding the level of education, the group of secondary level had the highest proportion (45.2\%). According to the marital status, the single people made up 55.1\% of respondents, while the group of widowing and divorced had the lowest proportion of $6.4 \%$ (table 1) (Table 1).

Approximately all the respondents (98.8\%) claimed that living in unsanitary conditions exposed to health risks. For these people, the occurrence of diseases and epidemics represented the major threats (93\%). Against, a small proportion (2.9\%) of them expressed that the unsanitary environments had a major negative impact on the pollution of the ambient air. In addition, 5.2\% considered that living in this unsanitary environment could have a negative effect on the quality of life and $1.2 \%$ estimated that life expectancy could decline (Table 1). 
Table 1: Sociodemographic characteristics of the population surveyed and their perception of health risks related to exposure to unsanitary in urban slums of Bouaké, 2019.

\begin{tabular}{|c|c|c|c|}
\hline Demographics & $\begin{array}{l}\text { Children } \\
(\text { No. }=211)\end{array}$ & $\begin{array}{l}\text { Householders } \\
(\text { No. }=212)\end{array}$ & $\begin{array}{c}\text { Overall } \\
(\text { No. }=423)\end{array}$ \\
\hline \multicolumn{4}{|l|}{ Age (years) } \\
\hline Means (range) & $13.8(9-15)$ & $42.4(21-79)$ & $28.2(9-79)$ \\
\hline Standard Deviation & \pm 1.4 & \pm 10.9 & \pm 16.3 \\
\hline Median & 14 & 42 & 21 \\
\hline \multicolumn{4}{|l|}{$\begin{array}{l}\text { Seniority in the urban slums } \\
\text { (years) }\end{array}$} \\
\hline Means (range) & $10.2(1-15)$ & $17.9(1-74)$ & $14.0(1-74)$ \\
\hline Standard Deviation & \pm 4.3 & \pm 12.1 & \pm 9.8 \\
\hline Median & 11 & 16 & 12.5 \\
\hline Gender & No. $(\%)$ & No. $(\%)$ & No. $(\%)$ \\
\hline Male & $130(61.6)$ & $135(63.7)$ & $265(62.6)$ \\
\hline Female & $81(38.4)$ & $77(36.3)$ & $158(37.4)$ \\
\hline \multicolumn{4}{|l|}{ Profession } \\
\hline Crafts & $47(22.3)$ & $100(47.2)$ & $147(35.7)$ \\
\hline Unemployed & $24(11.4)$ & $66(31.1)$ & $90(21.3)$ \\
\hline Civil servants \& Employees & $1(0.5)$ & $35(16.5)$ & $36(8.5)$ \\
\hline Pupils / Students & $139(65.8)$ & $11(5.2)$ & $150(35.5)$ \\
\hline \multicolumn{4}{|l|}{ Marital status } \\
\hline Married & $6(2.8)$ & $157(74.1)$ & $163(38.5)$ \\
\hline Single & $202(95.7)$ & $31(14.6)$ & $233(55.1)$ \\
\hline Widow(er) / Divorced & $3(1.4)$ & $24(11.3)$ & $27(6.4)$ \\
\hline \multicolumn{4}{|l|}{ Education level } \\
\hline Superior & $1(0.5)$ & $35(16.5)$ & $36(8.5)$ \\
\hline Secondary & $109(51.6)$ & $82(38.7)$ & $191(45.2)$ \\
\hline Primary & $56(26.5)$ & $40(18.8)$ & $96(22.7)$ \\
\hline Illiterate & $45(21.4)$ & $55(26)$ & $100(23.6)$ \\
\hline \multicolumn{3}{|c|}{ Perception of health risk related to exposure to unsanitary } & No.(\%) \\
\hline Diseases / epidemics & & & $389(93)$ \\
\hline Impact on life quality & & & $22(5.2)$ \\
\hline Air pollution & & & $12(2.9)$ \\
\hline Lack of social consideration & & & $10(2.4)$ \\
\hline Declining of life expectancy & & & $5(1.2)$ \\
\hline
\end{tabular}

The perception of health risks related to exposure to unsanitary was statistically associated with being a child or a head of household. The perception of health risks by children was $30 \%$ lower compared to adult heads of households $(\mathrm{p}=0.04)$. There was a statistical link between the profession and the perceived comfort living in precarious neighborhoods $(\mathrm{p}=0.035)$. Compared to the group of civil servants and service employees, the health risks perception of exposure to unsanitary was $60 \%(\mathrm{p}=0.031)$ lower with artisans and $70 \%$ lower with the unemployed $(\mathrm{p}=0.024)$ (Table 2). 
Table 2: Perception of health risks by populations exposed to unsanitary in urban slums of Bouaké according to socio-demographic characteristics, 2019.

\begin{tabular}{|c|c|c|c|c|}
\hline \multirow[t]{2}{*}{ Variables } & \multicolumn{2}{|c|}{$\begin{array}{c}\text { Perception of health risks related to } \\
\text { the exposure to unsanitary }\end{array}$} & \multirow[t]{2}{*}{$O R^{*}$} & \multirow[t]{2}{*}{$p$} \\
\hline & Yes (No., \%) & No (No., \%) & & \\
\hline \multicolumn{5}{|l|}{ Category $(n=423)$} \\
\hline children & $76(36.0)$ & $135(64.0)$ & 0.7 & 0.04 \\
\hline Householder & $97(45.8)$ & $115(54.2)$ & & \\
\hline \multicolumn{5}{|l|}{ Seniority in the urban slums $(n=423)$} \\
\hline$<13$ years & $169(80.1)$ & $42(19.9)$ & 0.8 & 0.40 \\
\hline$\geq 13$ years & $162(76.4)$ & $50(23.6)$ & & \\
\hline \multicolumn{5}{|l|}{ Gender $(n=423)$} \\
\hline Male & $115(43.4)$ & $150(56.6)$ & 1.3 & 0.176 \\
\hline Female & $58(36.7)$ & $100(63.3)$ & & \\
\hline \multicolumn{5}{|l|}{ Education level $(n=423)$} \\
\hline Illiterate & $49(49.0)$ & $51(51.0)$ & 1 & \\
\hline Primary & $36(37.5)$ & $60(62.5)$ & 1.6 & 0104 \\
\hline Secondary & $75(39.3)$ & $116(60.7)$ & 1.5 & 0.11 \\
\hline Superior & $13(36.1)$ & $23(63.9)$ & 1.7 & 0183 \\
\hline \multicolumn{5}{|l|}{ Profession $(n=423)$} \\
\hline Pupils / Students & $53(35.3)$ & $97(64.7)$ & 0.6 & 0242 \\
\hline Civil servants/Employees & $7(24.1)$ & $22(75.9)$ & 1 & \\
\hline Crafts & $88(45.4)$ & $106(54.6)$ & 0.4 & 0031 \\
\hline Unemployeds & $25(50.0)$ & $25(50.0)$ & 0.3 & 0024 \\
\hline \multicolumn{5}{|l|}{ Marital status $(n=423)$} \\
\hline Single & $87(37.3)$ & $146(62.7)$ & 0.8 & 0807 \\
\hline Married & $83(45.9)$ & $98(54.1)$ & 0.6 & 0461 \\
\hline Widow (er)/Divorced & $3(33.3)$ & $6(66.7)$ & 1 & \\
\hline
\end{tabular}

* Crude OR.

The logistic regression shows that the perception of health risks associated with exposure to unsanitary was statistically associated with the age of the population $(\mathrm{p}=0.0152)$ and the number of years of residence $(\mathrm{p}=0.0156)$ in urban slums (Table 3).

Table 3: Logistic model of the perception of health risks related to the exposure to unsanitary and sociodemographic characteristics of the inhabitants, Bouaké, 2019.

\begin{tabular}{lccc}
\hline Variables & OR* $^{*}$ & CI95\% & $p$-value \\
\hline Age & 1.0536 & 1.0101 to 1.0989 & $\mathbf{0 . 0 1 5 2}$ \\
Seniority in urban slums & 0.9513 & 0.9136 to 0.9906 & $\mathbf{0 . 0 1 5 6}$ \\
Child / Householder & 0.3996 & 0.1334 to 1.1967 & 0.1012 \\
Gender (Yes / No) & 0.6610 & 0.3965 to 1.1018 & 0.1122 \\
Profession & 0.9601 & 0.7394 to 1.2466 & 0.7597 \\
Marital status & 0.7087 & 0.4202 to 1.1954 & 0.1967 \\
Education Level & 0.9687 & 0.7392 to 1.2695 & 0.8176 \\
Seniority (Yes / No) & 1.1346 & 0.6081 to 2.1167 & 0.6915 \\
Constant & - & -- & 0.0001 \\
\hline
\end{tabular}

* Adjusted OR

\section{DISCUSSION}


These studies were designed to determine the perception of health risks by people living in urban slums. The results showed that perception was related to age and length of residency in these slums. Seniors who lived for a time in these areas had a better perception of the health risks facing unsanitary. People have claimed that living in unsanitary conditions could lead to diseases and epidemics. By cons, seniors who have spent more time in urban slums have become accustomed to this unsanitary living. More people earn in age and living for a long time in these urban slums, their level of perception of health risks decreases. This shows the plausibility of acclimatization to unsanitary by people with long-term residence in the slums. Thus, in most cases, this familiarization leads to ignorance by these populations of the sources and effects of environmental degradation and health risks (Kassoum, 2007). Moreover, in this study, almost all unaware that unsanitary could pollute the air and therefore lead to respiratory diseases. Most respondents did not know that living in unsanitary conditions could negatively impact life quality and reduce life expectancy. This evidence has been identified in other works which stipulated that urban slums dwellers mostly ignored the voice and the factors of disease transmission and medium- and long-term consequences (Harpham and Stephens, 1991; Patz et al., 2004).

In this research, the occupation and education level were respectively related to the perception of comfort living in unsanitary urban slums. For example, poor people like artisans and unemployed perceived less unsanitary and his effects in urban slums. These findings are consistent with the works which showed that the level of education and occupations of individuals are the most important determinants of the perception of health risks related to the exposure to household and environmental waste (Deza, 2017; Djéké, 2015; Sanni et al., 2016). Approximately all the respondents $(98.8 \%)$ in the study perceived that living in urban slums exposed to the risk of diseases developing. For in urban slums, poor people live in poor shelter, crowded, without access to public services (water, electricity, sanitation) that are the etiologies of many diseases that occurred.

Similarly, there is a lack of provision for waste disposal, excreta, and others so that people often live among rotting waste and unhygienic in a fetid atmosphere. Commonly these slums are infested with rodents and insects that disseminate diseases (Kassoum, 2007). Also, the prolonged exposition to bad smells, to solid and liquid waste increases the risk of diseases developing (Nsengiyumva, 2013). This is the consequence of rapid and uncontrolled urbanization of cities in developing countries, particularly in Africa (Harpham and Stephens, 1991). Unsanitary is the basis of the poor health of the people living in these urban slums.

\section{CONCLUSION}

This study showed that more people are aging with long-term residence in urban slums no longer they perceived the unsanitary as a factor that can affect their health. Also, this bad perception of unsanitary was linked to poor education and ignorance of voices and factors of disease transmission and the health consequences generated. In this context, information education and communication activities on risk-awareness have to be undertaken for residents of urban slums especially to the older ones. These actions can help them improve the health of their environment even the lack of public services (water, electricity, sanitation). 


\section{REFERENCES}

Clerc, V., Criqui, L., and Josse, G., (2017). Urbanisation autonome: pour une autre action urbaine sur les quartiers précaires. Métropolitiques 8. halshs-02021395. 7 décembre 2017.

Deza, A.D., (2017). Cartographie de la pauvreté non financière dans le district d'Abidjan à partir du recensement général de la population et de l'habitat 2014 de la Côte d'Ivoire. Observatoire démographique et statistique de l'espace francophone $1^{\text {ère }}$ Ed. 32 p. Québec, Université Laval. Collection : Rapports de recherche de l'ODSEF.

Djéké, A.E.B., (2015). Comportement en hygiène environnementale et impact sur la santé des ménages du quartier Koko de Bouaké. Thèse Médecine : $\mathrm{n}^{\circ}$ 474/15. Retrieved on $2^{\text {nd }}$ November, 2019 from: http:// archives.uvci.edu.ci > data > UAO > THESE_637055421346821900

Gaisie, S.K., (1980). Some aspects of socio-economic determinants of mortality in tropical Africa. Population Bulletin $\mathrm{n}^{\circ} 13: 16-25$. Retrieved on $2^{\text {nd }}$ November, 2019 from: https://www.ncbi.nlm.nih.gov/pubmed/12262582

Harpham, T., and Stephens, C., (1991). Urbanization and health in developing countries. World Health Statistics Quarterly. 44, 62-69.

Hayward, E., Ibe, C., Young, J.H., Potti, K., Jones, P., Pollack, C.E., and Gudzune, K.A., (2015). Linking social and built environmental factors to the health of public housing residents: a focus group study. BMC Public Health $15,351$. https://doi.org/10.1186/s12889-015-1710-9

Kassoum, T., (2007). De la Sensibilisation des Populations à la Gestion de l'Environnement Urbain dans les Quartiers Précaires De la Ville d'Abidjan. African Population Studies. Vol. 22(2). https://doi.org/10.11564/22-2-333

Ngnikam, E., Mougoue, B., and Tietche, F., (2007). Eau, Assainissement et impact sur la santé : étude de cas d'un écosystème urbain à Yaoundé. Actes des JSIRAUF 14. 13p. Retrieved on 2nd November, 2019 from: http://https://docplayer.fr/7688312-Eau-assainissement-et-impact-sur-la-sante-etude-de-cas-d-un-ecosysteme-urbaina-yaounde.html.

Nsengiyumva, E., (2013). Les facteurs déterminant le risque associé à l'habitat insalubre en milieu urbain. Une étude transversale à visée analytique réalisée en commune urbaine de Buyenzi au Burundi - Mémoire EDUS 2013. 71p. Retrieved on 2nd November, 2019 from: https://www.memoireonline.com/03/14/8782/Les-facteurs-determinant-lerisque-associe--1-habitat-insalubre-en-milieu-urbain-Une-etude-tr.html

Patz, J.A., Daszak, P., Tabor, G.M., Aguirre, A.A., Pearl, M., Epstein, J., Wolfe, N.D., Kilpatrick, A.M., Foufopoulos, J., Molyneux, D., Bradley, D.J., and Working Group on Land Use Change and Disease Emergence, (2004). Unhealthy landscapes: Policy recommendations on land use change and infectious disease emergence. Environment and Health Perspectives. 112, 1092-1098. https://doi.org/10.1289/ehp.6877

Prüss-Üstün, A., Corvalán, C.F., Organization, W.H., (2006). Prévenir la maladie grâce à un environnement sain: une estimation de la charge de morbidité imputable à l'environnement: résumé. 2006 ed. 19p. Paris, France. WHO Library Cataloguing-in-Publication Data

Prüss-Üstün, A., Wolf, J., Corvalán, C.F., Bos, R., and Neira, M., (2016). Preventing disease through healthy environments: a global assessment of the burden of disease from environmental risks, 2016 ed. 176p. Paris, France. WHO Library Cataloguing-in-Publication Data. 
Sanni, B., David, B.M., and Christophe, H.S., (2016). Perceptions Des Nuisances Environnementales Liées Aux Déchets Solides Ménagers Dans Les Centres Urbains Du Nord-Bénin : Cas Des Villes De Parakou, Djougou, Kandi Et Malanville. European Scientific Journal. 12, 349. https://doi.org/10.19044/esj.2016.v12n23p349

Sy, I., Keita, M., Traoré, D., Koné, B., Bâ, K., Wedadi, O.B., Fayomi, B., Bonfoh, B., Tanner, M., and Cissé, G., (2014). Eau, hygiène, assainissement et santé dans les quartiers précaires à Nouakchott (Mauritanie) : contribution à l'approche écosanté à Hay Saken. Revue Électronique En Science Environnementale. https://doi.org/10.4000/vertigo.14999

Urbandt, I., (1963). Insalubrity. La Semana Medica. 122, 135-138. 